\title{
Prepurification of $\alpha$-lactalbumin with ultrafiltration ceramic membranes from acid casein whey: study of operating conditions
}

\author{
Arabelle MULLER ${ }^{\mathrm{a}}$, Bernard CHAUFER ${ }^{\mathrm{b} *}$, Uzi MERIN $^{\mathrm{c}}$, Georges DAUFIN $^{\mathrm{a}}$ \\ ${ }^{a}$ Laboratoire de Recherches de Technologie Laitière, INRA, 65, rue de Saint-Brieuc, \\ 35042 Rennes Cedex, France \\ ${ }^{\text {b }}$ Laboratoire des Procédés de Séparation, Université Rennes I, CS 74205, 35042 Rennes Cedex, France \\ c Dairy Science Laboratory, A.R.O., The Volcani Center, PO Box 6, Bet Dagan 50250, Israel
}

(Received 27 July 2001; accepted 2 September 2002)

\begin{abstract}
A promising way to produce purified $\alpha$-lactalbumin ( $\alpha$-LA) is to perform a two-step cascade. The first step of pre-purifying presented herein, consists of ultrafiltration (UF) fractionation of acid casein whey, aiming at increasing the purity of $\alpha$-LA in the filtrate by total retention of bovine serum albumin and immunoglobulins with only a limited transmission of $\beta$-lactoglobulin. The outcome of the present work is a guideline which includes the proper selection of ceramic UF membrane molecular mass cut-off (MMCO) (from 150 to $300 \mathrm{~kg} \cdot \mathrm{mol}^{-1}$ ), operating conditions (physico-chemistry, hydrodynamics) and operation mode for achieving satisfactory performance. Irreversible membrane fouling, mainly due to $\beta$-lactoblobulin $(\beta-\mathrm{LG})$, the major protein of the feed solution, and physico-chemical characteristics of the whey protein sources (initial $\alpha$-LA purity and concentration; heat denaturation of proteins) were shown as selection parameters of prime importance with regard to the target of the prepurification step. Whey protein concentrate in liquid form (PS 90) was to be preferred versus the same grade in powder form and the less concentrated liquid (PS 75). By processing that liquid PS 90, $\alpha$-LA purity in the permeate was increased from around 0.25 in the initial feed to around 0.44 with a yield of around 0.53 with Céram membranes of MMCO of $300 \mathrm{~kg} \cdot \mathrm{mol}^{-1}$. Stationary ultrafiltration flux was around $64 \mathrm{~L} \cdot \mathrm{h}^{-1} \cdot \mathrm{m}^{-2}$ at a volume reduction ratio of 9 .
\end{abstract}

\section{$\alpha$-lactalbumin / whey / purity / ultrafiltration}

Résumé - Pré-purification de l' $\alpha$-lactalbumine par ultrafiltration de lactosérum acide sur membrane céramique : étude des conditions opératoires. La production d' $\alpha$-lactalbumine $(\alpha$-LA) de pureté élevée peut se faire par une cascade de 2 opérations, dont la première, présentée ici, est une étape de pré-purification. Il s'agit d'un fractionnement par ultrafiltration d'un lactosérum de caséine acide afin d'obtenir une pureté en $\alpha$-LA améliorée dans le filtrat en retenant totalement la sérum-albumine bovine et les immunoglobulines. Le présent travail débouche sur un recueil de recommandations qui inclut le choix du seuil de coupure de la membrane, des conditions physicochimiques et hydrodynamiques et du mode de conduite pour obtenir des performances satisfaisantes. Le colmatage irréversible de la membrane et les caractéristiques physico-chimiques de la source de protéines de lactosérum (pureté et concentration initiale en $\alpha$-LA ; dénaturation des

* Correspondence and reprints

Tel.: +332232357 53; fax: +332232357 65; e-mail: Bernard.Chaufer@univ-rennes1.fr 
protéines) sont des paramètres de toute première importance dans la réussite de cette étape de prépurification. Ainsi, le concentré de protéines de lactosérum (PS 90) liquide est à préférer à la forme poudre et au fluide liquide moins concentré (PS 75). Avec cette matière première (PS 90) liquide la pureté de l' $\alpha$-LA dans le perméat augmentait, passant d'environ 0,25 dans la matière première à 0,44 avec un rendement de 0,53 après traitement sur membrane Céram de seuil de coupure $300 \mathrm{~kg} \cdot \mathrm{mol}^{-1}$. Le flux d'ultrafiltration stationnaire était de l'ordre de $64 \mathrm{~L} \cdot \mathrm{h}^{-1} \cdot \mathrm{m}^{-2}$ à un facteur de réduction volumique de 9 .

$\alpha$-lactalbumine / lactosérum / pureté / ultrafiltration

\section{INTRODUCTION}

Among the individual soluble milk proteins $\alpha$-lactalbumin, $\alpha$-LA has been the interest of many researchers provided it can be produced on a large scale with a high purity and limited denaturation. $\alpha$-LA has been claimed as a food additive in baby formula and other food uses owing to its high content in tryptophane and nutritional value $[1,17,38,40]$; as a medicine due to its high cytotoxicity (biological properties), as evidenced for the same protein from human origin [14, 43]; as regulating sleep and the biological clock [16]; as a contraceptive in its native form [41] ; and as protective against ethanol- and stressinduced gastric mucosal injury [28].

In milk and whey $\alpha$-LA is known to be in its native state, the $\mathrm{N}$-conformer, or at an "A-state" (acidic), or at numerous forms intermediate between the $\mathrm{N}$ and $\mathrm{A}$ states [47] depending on various physico-chemical conditions [5]. A few reports elaborate on the different structural forms of $\alpha$-LA and their physico-chemical behaviour, including their propensity for aggregation [5, 21, 22, 43]. De la Fuente et al. [8] report that differences in functionality of whey protein concentrates from cheese or acid casein whey (assessed by size exclusion chromatography with refractive index and light scattering determination and electrophoreses) are more related to the processes used for cheese or casein manufacture than to the concentrate manufacturing processes (ultrafiltration, diafiltration, evaporation, spray drying).
Whey, the major source for $\alpha$-LA, is a co-product of cheese-making and of the casein industry. It contains about $20 \%$ of the milk proteins $\left(6 \mathrm{~g} \cdot \mathrm{L}^{-1}\right)$ and is produced at an annual rate exceeding 97 million tons in the European Community, North America and Oceania with a yearly increase of around 2\% [18]. Whey fractionation processes have been developed for about 25 years [26] with the aim of reducing effluent disposal [27] and of taking advantage of the various properties of the protein fractions $[15,20]$. Consequently, many researchers have sought enriched $\alpha$-LA fraction from acid and sweet whey of different origin. Outinen et al. [32] claim that strong anion exchange chromatography followed by a two-step elution with first dionised water then weak aqueous $\mathrm{NaCl}$ yields two successive fractions enriched in $\alpha-\mathrm{LA}$ and $\beta-\mathrm{LG}$, respectively. Most of the proposed schemes take advantage of selective and reversible aggregation of $\alpha-\mathrm{LA}$ at acidic $\mathrm{pH}$ as the first step in order to separate it from the other whey proteins by sedimentation [33, 34, 42] or as a retentate after several pre-filtration steps such as microfiltration (MF), UF and diafiltration (DF) $[9,37,48]$ and solubilisation at $\mathrm{pH}$ 7.0-7.5 [33]. Several investigators have proposed a 2-step process for the recovery of $\alpha$-LA, where the first step is based on its heat precipitation at $\mathrm{pH} \sim 3$, below its isoelectric $\mathrm{pH}[4,9,33-35]$. In this scheme $\beta$-LG remains soluble; the co-precipitated fraction of $\alpha$-LA, bovine serum albumin (BSA), and immunoglobulins (Ig), is solubilised by adjusting its $\mathrm{pH}$ to $\sim 7$ at room temperature with the possible addition of 
calcium ions [3]. $\alpha$-LA purity reported for the above 2 -step process is in the range $62-64 \%$ with a yield of $76-80 \%$, respectively $[9,35]$. Crossflow filtration was also reported to result in enriched $\alpha$-LA permeate after a proper choice of membrane cutoffs from milk and whey [19]. When whey proteins are in a soluble form, filtration through various MMCO membranes, $5 \mathrm{~kg} \cdot \mathrm{mol}^{-1}$ [37] or $100 \mathrm{~kg} \cdot \mathrm{mol}^{-1}$ [2], results in a permeate enriched in $\alpha$-LA. The latter is further purified by DF using $1.5-2.0$ or $10 \mathrm{~kg} \cdot \mathrm{mol}^{-1}$ membranes. These processes result in limited purity of $\alpha-\mathrm{LA}$ (around 0.3 ) due to transmission of $\beta-\mathrm{LG}$ (molecular mass $\left.(\mathrm{MM})=36 \mathrm{~kg} \cdot \mathrm{mol}^{-1}\right)$ and glycomacropeptide (GMP) $\left(\mathrm{MM}=7 \mathrm{~kg} \cdot \mathrm{mol}^{-1}\right)$, which are close in molecular size and are present in rennet whey at nearly the same concentration as $\alpha$-LA $\left(\sim 1 \mathrm{~g} \cdot \mathrm{L}^{-1}\right)$. Moreover, recovery of $\alpha$-LA is low due to its partial retention by the UF membrane, although a reported usage of a combined UF-DF process enables one to obtain a fraction with enhanced yield [31]. Available whey protein concentrates (WPC) on the market lie between $60 \%$ and $90 \%$ protein referred to as dry matter. Purity of $\alpha$-LA in powder is within $15-40 \%$ (vs. total protein content). Depending on whey processing and the industrial products the ratio of $\alpha$-LA to $\beta$-LG ranges from 1 to 2 .

The critical analysis of the performance of such processes highlights that the moderate final purity of $\alpha$-LA partly results from the limited purity of this protein in the processed feed. Consequently, we have studied a 2-step process, where the 1st step was targeted at pre-purifying $\alpha$-LA. The 2nd step (final purification by using either ultrafiltration or precipitation operation) will be detailed in a forthcoming paper.

In the present work, we present the first step of such a cascade. It consisted of a membrane separation proposed to increase $\alpha$-LA purity in the permeate to overcome the above drawbacks [30]. More precisely, it consisted of: (i) utilising reconstituted acid casein whey from WPC, which is devoid of GMP which contaminates $\alpha$-LA fractions obtained when using rennet whey, (ii) aiming to a close to zero BSA and $\operatorname{IgG}$ concentration in the filtrate, and (iii) finding the best operating parameters to achieve enhanced $\alpha$-LA purity and yield. We know that such an acid casein whey is produced according to a general procedure, acidification of milk at around $45^{\circ} \mathrm{C}$ to a $\mathrm{pH}$ between 4.0 and 4.5 , which changes the $\alpha$-LA structure to the so-called "A-state" conformers whose properties are markedly different from those of the native protein; amoung them is the increased propensity for self-association, which is the basis for most of the purifying processes relying upon $\alpha$-LA aggregation, cited above. In the part of our work aimed at finding out a process scheme for achieving high $\alpha$-LA purity, we did not pay attention to the structural changes undergone by $\alpha$-LA. Such a significant concern will be the core of further experimentations, with the aim of studying the process-structure relations with that new purification process and various $\alpha$-LA sources.

In the first part of this work, operating process parameters such as protein denaturation, protein concentration, physicochemistry ( $\mathrm{pH}$, ionic strength), membrane pore size and operation hydrodynamics were systematically investigated in order to determine which conditions ensure as high as possible an $\alpha$-LA transmission and yield with decreased BSA and IgG transmission. In the second part, a few experiments were performed in the best conditions determined in the first part in order to propose a concentration operation with satisfactory $\alpha$-LA purity and recovery in the filtrate and to determine the level of impurity caused by the other proteins.

\section{MATERIALS AND METHODS}

\subsection{Feed material and physico- chemical parameters}

The hydrochloric acid Whey Protein Concentrates (Protarmor, Armor Proteines, 

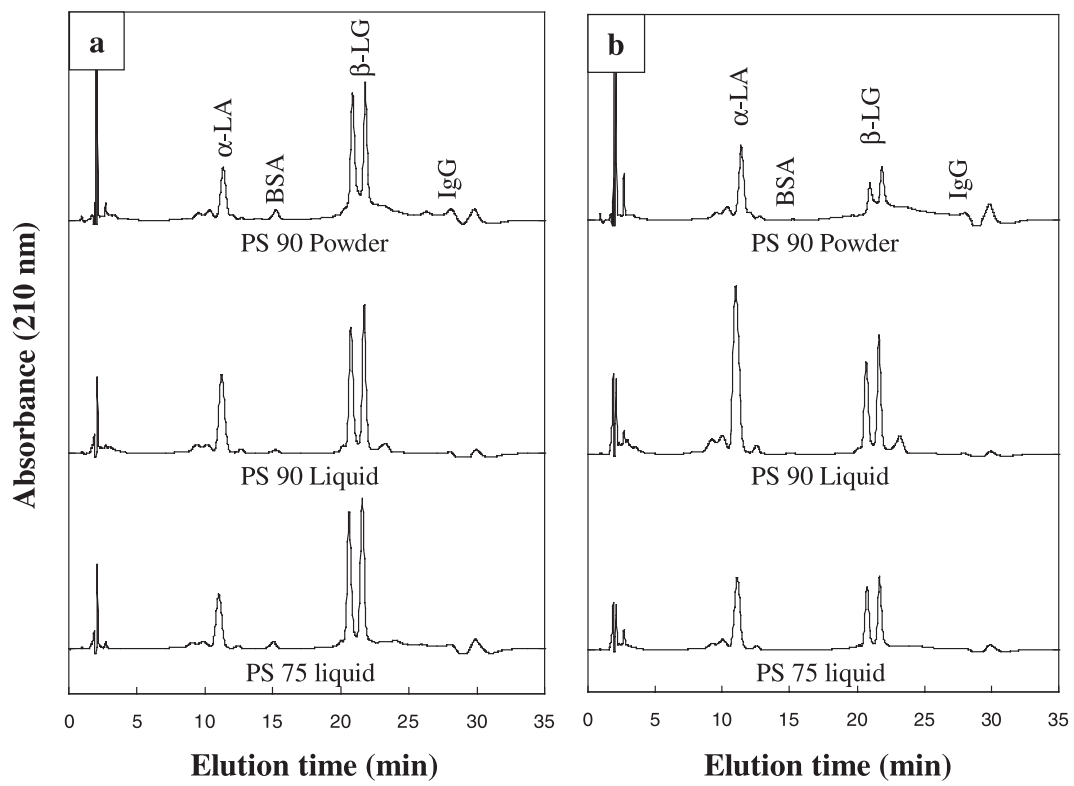

Figure 1. Reverse phase HPLC profiles of the three feed solutions. (a): feed solution. (b): permeate (average composition, scale expanded by 3.63 for comparison to the feed).

St-Brice-en-Coglès, France) used in this work were as follows: PS 75 (as a liquid) was frozen and used after thawing. PS 90 (as a liquid) was first clarified by $\mathrm{MF}$ $(0.1 \mu \mathrm{m})$, frozen and kept at $-18{ }^{\circ} \mathrm{C}$ until thawing. PS 90 (as a powder) was reconstituted with pure water before each experiment and clarified by adjusting the $\mathrm{pH}$ to 5.0 , to cause precipitation of denatured proteins, and was then decanted after holding at $4{ }^{\circ} \mathrm{C}$ for $5 \mathrm{~h}$. To check the influence of the pre-filtration, the freezing and keeping quality of the frozen mass, and the reconstitution and decanting processes on the protein properties, samples were analysed by reverse phase high-pressure liquid chromatography (RP-HPLC) as described by Muller et al. [31]. It should be noted that the shoulder (15-25\%) before the peak of $\alpha$-LA (Fig. 1) has been identified as one lactose molecule linked to $\alpha$-LA by electrospray ionisation-mass spectrometry [6]. The overall peak was then considered as $\alpha$-LA.
Protein stability in the 3 feeds was studied at $50{ }^{\circ} \mathrm{C}$ in a wide range of ionic strength, I (0.0-1.0 mol. $\left.\mathrm{L}^{-1}\right)$ and $\mathrm{pH}(2.0$ 9.0) by adjusting I using $\mathrm{NaCl}$ and $\mathrm{pH}$ by adding $3 \mathrm{~mol} \cdot \mathrm{L}^{-1} \mathrm{HCl}$ or $3 \mathrm{~mol} \cdot \mathrm{L}^{-1} \mathrm{NaOH}$. Stability was measured as turbidity to determine protein denaturation (increase in turbidity meant denaturation). It was assessed through optical density measured at $600 \mathrm{~nm}, \mathrm{OD}_{600}$ with an experimental error of 0.01 absorbance unit.

The PS 90 powder was selected for the parametric study of the operating conditions because it resulted in a similar protein profile to the others (Fig. 1) and was easily reconstituted at high reproducibility at any protein concentration needed (Tab. I).

\subsection{Cross-flow filtration rig, mem- branes and operating conditions}

Cross flow filtration was performed with a laboratory rig, as previously described [7]. Five tubular inorganic membranes were 
Table I. Composition of the three whey protein concentrates, WPC.

\begin{tabular}{lccc}
\hline & PS 90 (powder) & PS 90 (liquid) & PS 75 (liquid) \\
\hline Protein concentration $\left(\mathrm{g} \cdot \mathrm{L}^{-1}\right)$ & $(-)$ & 18 & 13 \\
\hline Purity of individual proteins $\%$ & 14.0 & 25.0 & 17.0 \\
$\alpha-\mathrm{LA}$ & 76.0 & 73.0 & 79.0 \\
$\beta-\mathrm{LG}$ & 2.7 & 1.2 & 2.0 \\
$\mathrm{BSA}$ & $7.3^{*}$ & 0.8 & 2.0 \\
$\mathrm{IgG}$ & & & \\
& $5.0^{* *}$ & $7.0^{* *}$ & 4.7 \\
$\mathrm{pH}{ }_{50}{ }^{\circ} \mathrm{C}$ (origin) & $4^{* * *}$ & $4^{* * *}+1^{* *}$ & $2^{* * *}$ \\
Filtration steps & Yes & $\mathrm{No}$ & No \\
Drying & Room temperature & Frozen $\left(-18^{\circ} \mathrm{C}\right)$ & Frozen $\left(-18^{\circ} \mathrm{C}\right)$ \\
Storage & Decantation, & $\mathrm{MF} 0.1 \mu \mathrm{m}$, & None \\
Pretreatment & $\mathrm{pH} 5.0^{* *}$ & $\mathrm{pH} 7.0^{* *}$ & \\
&
\end{tabular}

* Unresolved denatured $\beta$-LG + IgG (one broad peak in HPLC); ** pretreatment step performed at the laboratory; $* * *$ industrial steps.

tested: a mono-tube Carbosep of $6 \mathrm{~mm}$ inner-diameter: M14 $(0.14 \mu \mathrm{m})$ and $\mathrm{M} 1$ $\left(150 \mathrm{~kg} \cdot \mathrm{mol}^{-1} ; 20.6 \mathrm{~nm}\right)$ (Orelis, formerly TechSep, St-Maurice-de-Beynost, France); and a 3-channel Céram tube of $3.6 \mathrm{~mm}$ inner diameter, with a range of $3 \mathrm{MMCO}$ 300,220 and $150 \mathrm{~kg} \cdot \mathrm{mol}^{-1}$ (Tami Industries, Nyons, France). This range of cutoffs was expected to provide nearly total retention of Ig and BSA under appropriate operating conditions. The membrane area was $0.0226 \mathrm{~m}^{2}$ for the Carbosep membranes and $0.045 \mathrm{~m}^{2}$ for the Céram ones. Prior to a filtration experiment each membrane was conditioned and cleaned as described by Muller et al. [31]: tangential flow velocity, $\mathrm{v}=7 \mathrm{~m} \cdot \mathrm{s}^{-1} ;$ constant flux $=$ $50 \mathrm{~L} \cdot \mathrm{h}^{-1} \cdot \mathrm{m}^{-2} ; \mathrm{P} 3$ - Ultrasil 13 (Henkel-Ecolab, Issy-les-Moulineaux, France) $1 \% \mathrm{w} / \mathrm{vol}$, $\mathrm{pH} 13,85^{\circ} \mathrm{C}$; followed by $6 \times 10^{-2} \mathrm{~mol} \cdot \mathrm{L}^{-1}$ $\mathrm{HNO}_{3}, \mathrm{pH}=1.0,60^{\circ} \mathrm{C}, 20 \mathrm{~min}$.

The Carbosep membranes were operated with PS 90 powder under the following conditions: whey protein concentration, $\mathrm{C}$ (7 and $\left.35 \mathrm{~g} \cdot \mathrm{L}^{-1}\right) ; \mathrm{pH}(5.0-7.0) ; \mathrm{I}(0.0$ $\left.1.0 \mathrm{~mol} \cdot \mathrm{L}^{-1}\right)$; temperature, $\mathrm{T} 50{ }^{\circ} \mathrm{C}$; v $(2.0$, $4.5,7.0 \mathrm{~m} \cdot \mathrm{s}^{-1}$; wall shear stress, $\tau_{\omega}=25$, $70,130 \mathrm{~Pa}$, respectively); transmembrane pressure, $\Delta \mathrm{P} \quad(0.3-3.5$ bar); permeate withdrawal under atmospheric pressure and recycled; volume reduction ratio, $\mathrm{VRR}=1$ (Tab. II).

The Céram membranes were operated with the 3 feed materials PS 90 powder, PS 90 liquid and PS 75 liquid at a concentration of $7 \mathrm{~g} \cdot \mathrm{L}^{-1}$. Other conditions were as follows: $\mathrm{I}=0.2 \mathrm{~mol} \cdot \mathrm{L}^{-1} ; \mathrm{T}=50{ }^{\circ} \mathrm{C}, \mathrm{v}=$ $6 \mathrm{~m} \cdot \mathrm{s}^{-1}\left(\tau_{\omega}=130 \mathrm{~Pa}\right) ; \Delta \mathrm{P}=1.0 \mathrm{bar}$ and increasing VRR (Tab. II). These experiments were run at a dynamic counter pressure mode with the permeate circulating co-current to the retentate to get a uniform constant transmembrane pressure along the whole filtering path [12].

Two types of experiments were used in the present study: (i) varying $\Delta \mathrm{P}$, starting at 0.3 bar for $45 \mathrm{~min}$ and increasing up to 1.5 bar (with MF) or 3.5 bar (with UF) at a rate of $2.0 \mathrm{bar} \cdot \mathrm{h}^{-1}$; and (ii) constant $\Delta \mathrm{P}$ for $4 \mathrm{~h}$, which was used in most of the experiments, to assess the variations of $\mathrm{J}$ and transmission, $\mathrm{Tr}$, vs. time.

\subsection{Calculations}

Membrane fouling was measured by calculating the hydraulic resistances (error given in brackets): clean membrane, 
Table II. Operation conditions with Carbosep and Céram membranes at $\mathrm{T}=50{ }^{\circ} \mathrm{C}$.

\begin{tabular}{|c|c|c|c|c|c|c|}
\hline Procedure & $\mathrm{pH}$ & $\begin{array}{c}\mathrm{C} \\
\left(\mathrm{g} \cdot \mathrm{L}^{-1}\right)\end{array}$ & $\begin{array}{c}\mathrm{I} \\
\left(\mathrm{mol} \cdot \mathrm{L}^{-1}\right)\end{array}$ & Membrane & $\begin{array}{c}\mathrm{v} \\
\left(\mathrm{m} \cdot \mathrm{s}^{-1}\right)\end{array}$ & $\Delta \mathrm{P}$ range \\
\hline
\end{tabular}

1. Membrane cut-off and transmembrane pressure $(\mathrm{VRR}=1)$

\begin{tabular}{llllccc}
\hline Varying $\Delta \mathrm{P}$ & 7.0 & 35 & 0.2 & M14 & 7.0 & $\mathbf{0 . 3 - 1 . 5}$ \\
Varying $\Delta \mathrm{P}$ & 7.0 & 35 & 0.2 & M1 & 7.0 & $\mathbf{0 . 3}-\mathbf{3 . 5}$ \\
Varying $\Delta \mathrm{P}$ & 7.0 & 35 & 0.2 & $\mathrm{M} 1$ & 7.0 & $\mathbf{0 . 3}-3.5$ \\
Constant $\Delta \mathrm{P}$ & 7.0 & 35 & 0.2 & $\mathrm{M} 1$ & 7.0 & $\mathbf{1 . 0}$ \\
Constant $\Delta \mathrm{P}$ & 7.0 & 35 & 0.2 & $\mathrm{M} 1$ & 7.0 & $\mathbf{3 . 0}$
\end{tabular}

\section{Protein concentration $(\mathrm{VRR}=1)$}

\begin{tabular}{lcccccc}
\hline Varying $\Delta \mathrm{P}$ & 7.0 & $\mathbf{7}$ & 0.2 & $\mathrm{M} 1$ & 7.0 & $0.3-3.5$ \\
Varying $\Delta \mathrm{P}$ & 7.0 & $\mathbf{3 5}$ & 0.2 & $\mathrm{M} 1$ & 7.0 & $0.3-3.5$
\end{tabular}

3. Ionic strength $(\mathrm{VRR}=1)$

\begin{tabular}{lllllll}
\hline Varying $\Delta \mathrm{P}$ & 7.0 & 35 & $\mathbf{0 . 0}$ & $\mathrm{M} 1$ & 7.0 & $0.3-3.5$ \\
Varying $\Delta \mathrm{P}$ & 7.0 & 35 & $\mathbf{0 . 2}$ & $\mathrm{M} 1$ & 7.0 & $0.3-3.5$ \\
Varying $\Delta \mathrm{P}$ & 7.0 & 35 & $\mathbf{1 . 0}$ & $\mathrm{M} 1$ & 7.0 & $0.3-3.5$
\end{tabular}

4. Tangential flow velocity and $\mathrm{pH}(\mathrm{VRR}=1)$

\begin{tabular}{lllllll}
\hline Varying $\Delta \mathrm{P}$ & $\mathbf{5 . 0}$ & 35 & 0 & $\mathrm{M} 1$ & $\mathbf{2 . 0}$ & $0.3-3.5$ \\
Varying $\Delta \mathrm{P}$ & $\mathbf{5 . 0}$ & 35 & 0 & $\mathrm{M} 1$ & $\mathbf{7 . 0}$ & $0.3-3.5$ \\
Varying $\Delta \mathrm{P}$ & $\mathbf{6 . 0}$ & 35 & 0 & $\mathrm{M} 1$ & $\mathbf{4 . 5}$ & $0.3-3.5$ \\
Varying $\Delta \mathrm{P}$ & $\mathbf{7 . 0}$ & 35 & 0 & $\mathrm{M} 1$ & $\mathbf{2 . 0}$ & $0.3-3.5$ \\
Varying $\Delta \mathrm{P}$ & $\mathbf{7 . 0}$ & 35 & 0 & $\mathrm{M} 1$ & $\mathbf{7 . 0}$ & $0.3-3.5$
\end{tabular}

5. Céram membranes of $3 \mathrm{MMCO}-100,220$ and $300 \mathrm{~kg} \cdot \mathrm{mol}^{-1}$ (increasing VRR)

\begin{tabular}{lllllll}
\hline Constant $\Delta \mathrm{P}$ & 7.0 & 7 & 0.2 & Céram & 6.0 & 1.0
\end{tabular}

Bold-faced entry represents variable under study. Procedure: varying $\Delta \mathrm{P}$ : flux as a function of transmembrane pressure; Constant $\Delta \mathrm{P}$ : constant transmembrane pressure. C: protein concentration; I: ionic strength; v: tangential flow velocity; VRR: volume reduction ratio.

$\mathrm{R}_{\mathrm{m}}( \pm 0.05) ; \quad$ overall, reversible and irreversible fouling, $R_{f}( \pm 0.1), R_{r f}( \pm 0.1)$ and $R_{\text {if }}( \pm 0.1)$, respectively, using Darcy's law [44]. In certain cases the normalised fouling was calculated utilising the ratio of each of the above parameters, $R_{f}, R_{r f}$ and $\mathrm{R}_{\mathrm{if}}$, divided by $\mathrm{R}_{\mathrm{m}}( \pm 0.15)$.

Protein transmission $\left(\mathrm{Tr}=\frac{\mathrm{C}_{\mathrm{P}}}{\mathrm{C}_{\mathrm{r}}}\right.$ with $\mathrm{C}_{\mathrm{p}}$, $\mathrm{C}_{\mathrm{r}}$ protein concentration in the permeate, $\mathrm{p}$, and in the retentate, $\mathrm{r}$, respectively) was calculated with an error of $\leq 0.1$.
The relationship between transmission and pore radius (clean, fouled) was calculated by using Ferry's equation [11]: $\operatorname{Tr}=1-\lambda^{2}(2-\lambda)^{2}$ with $\lambda=\frac{\mathrm{r}_{\mathrm{s}}}{\mathrm{r}_{\mathrm{pf}}}, \mathrm{r}_{\mathrm{s}}:$ Stokes radius $(\mathrm{nm}) ; \mathrm{r}_{\mathrm{pf}}$ : fouled pore radius $(\mathrm{nm})$.

Protein purity, $\mathrm{P}\left(\mathrm{P}=\frac{\mathrm{C}_{\mathrm{i}}}{\Sigma \mathrm{C}}\right.$ with $\mathrm{C}_{\mathrm{i}}$, the concentration of protein $\mathrm{i}$ in a given stream and $\Sigma \mathrm{C}$, overall protein concentration in the stream) was assessed with a relative error $\leq 0.15$. 
The relative error on yield, $\mathrm{Y}\left(\mathrm{Y}=\frac{\mathrm{VC}_{\mathrm{p}}}{\mathrm{VC}_{\mathrm{f}}}\right.$, where: $\mathrm{V}$ volume; $\mathrm{C}_{\mathrm{p}}$ and $\mathrm{C}_{\mathrm{f}}$ protein concentration in the permeate and feed, respectively) was $\leq 0.2$.

\subsection{Experimental design and reproducibility}

Table II presents all the experiments performed in the first part of the work, which was devoted to the study of the different parameters that could influence protein transmission. The table is divided into subsections, which are related to the different parameters in the study.

The experimental design for studying the effects of $\mathrm{pH}$ and $\mathrm{v}$ was based upon 6 experiments: the extreme points $\{\mathrm{pH}=5.0$; $\left.\mathrm{v}=2.0 \mathrm{~m} \cdot \mathrm{s}^{-1}\right\} ;\left\{\mathrm{pH}=7.0 ; \mathrm{v}=2.0 \mathrm{~m} \cdot \mathrm{s}^{-1}\right\}$ and the central point duplicated $\{\mathrm{pH}=6.0$, $\left.\mathrm{v}=4.5 \mathrm{~m} \cdot \mathrm{s}^{-1}\right\}$. The parameters were coded according to 3 levels: $-1,0,+1$ and analysed with a multiple linear regression. The residual standard deviations calculated from the results of the experimental design were $1.5\left(\frac{R_{f}}{R_{m}}\right), 2.0\left(\frac{R_{i f}}{R_{m}}\right)$ and $0.09(\mathrm{Tr})$.

A few filtration experiments with different combinations (membrane, feed, operating conditions) were duplicated. The reproducibility for flux, $\mathrm{J}$ and protein transmission was good and the standard deviation low enough to allow the performing of a comparison of data obtained in a single experiment: $\mathrm{J} \pm 10 \mathrm{~L} \cdot \mathrm{h}^{-1} \cdot \mathrm{m}^{-2}$; Tr: $\alpha-\mathrm{LA} \pm 0.03$; $\beta-\mathrm{LG} \pm 0.02$; BSA and $\mathrm{IgG} \pm 0.05$.

\section{RESULTS AND DISCUSSION}

The protein composition of the three WPC used in this work is given in Table I. The protein's preliminary stability experiments $\left(50{ }^{\circ} \mathrm{C}, \mathrm{pH}=2.0\right.$ to 9.0 and $\mathrm{I}=0.0$ to $1.0 \mathrm{~mol} \cdot \mathrm{L}^{-1}$ ) showed that the whey proteins were stable (no increase in turbidity, $\mathrm{OD}_{600}$ ) and no denaturation (no peak broadening in HPLC) for the $\mathrm{pH}$ range 6.0-7.5, whatever the ionic strength [30].
The results were in good agreement with the literature data for individual whey proteins, which show salting out effect at $\mathrm{pH}<$ 5.0 [25] and denaturation at $\mathrm{pH}>8.0$ [45].

\subsection{Assessment of the effect of operating parameters}

Transmission of $\alpha-\mathrm{LA}$, the protein to be purified and that of BSA, the indicative protein to be retained, were selected as indicative of the operation performance.

\subsubsection{Membrane cut-off and transmembrane pressure}

As expected, flux obtained for the microfiltration Carbosep (M14-0.14 $\mu \mathrm{m}$ ) membrane was higher than for the UF (M1-20.6 nm) membrane; the larger the pore size, the higher the $\mathrm{J}$ for the $\Delta \mathrm{P}$ range studied (Fig. 2a).

Transmissions of $\alpha$-LA and BSA decreased as $\Delta \mathrm{P}$ increased regardless of the membrane used, with $\operatorname{Tr}_{\alpha-\mathrm{LA}}>\operatorname{Tr}_{\mathrm{BSA}}$ (Fig. 2b): (i) with the $0.14 \mu \mathrm{m}$ membrane, the transmission of both proteins remained over 0.8 and (ii) with the $20.6 \mathrm{~nm}$ membrane, $\operatorname{Tr}_{\alpha \text {-LA }}$ varied from 0.58 to 0.25 and $\operatorname{Tr}_{\mathrm{BSA}}$ from 0.18 to around 0.05 .

Calculation of the purity of $\alpha$-LA in the permeate relative to its initial concentration in the feed showed that the $0.14 \mu \mathrm{m}$ membrane did not result in increased purity at all. At the same time, with the $20.6 \mathrm{~nm}$ membrane, $\alpha$-LA purity increased by around $12 \%(0.15-0.17)$ while BSA purity decreased by $50 \%(0.02-0.01)$.

The decrease in $\operatorname{Tr}$ with $\Delta \mathrm{P}$ and $\mathrm{J}$ increase shows that irreversible fouling effects overcame the effect of concentration polarisation. The amplitude of Tr decrease varied according to not only the membrane pore size used but also to the relative increase in irreversible fouling: $\frac{R_{f}}{R_{m}}$, more pronounced for M1 (4.0) than for M14 (0.9). Those conditions corresponded to 13.8 and $59.6 \mathrm{~nm}$ fouled pore 

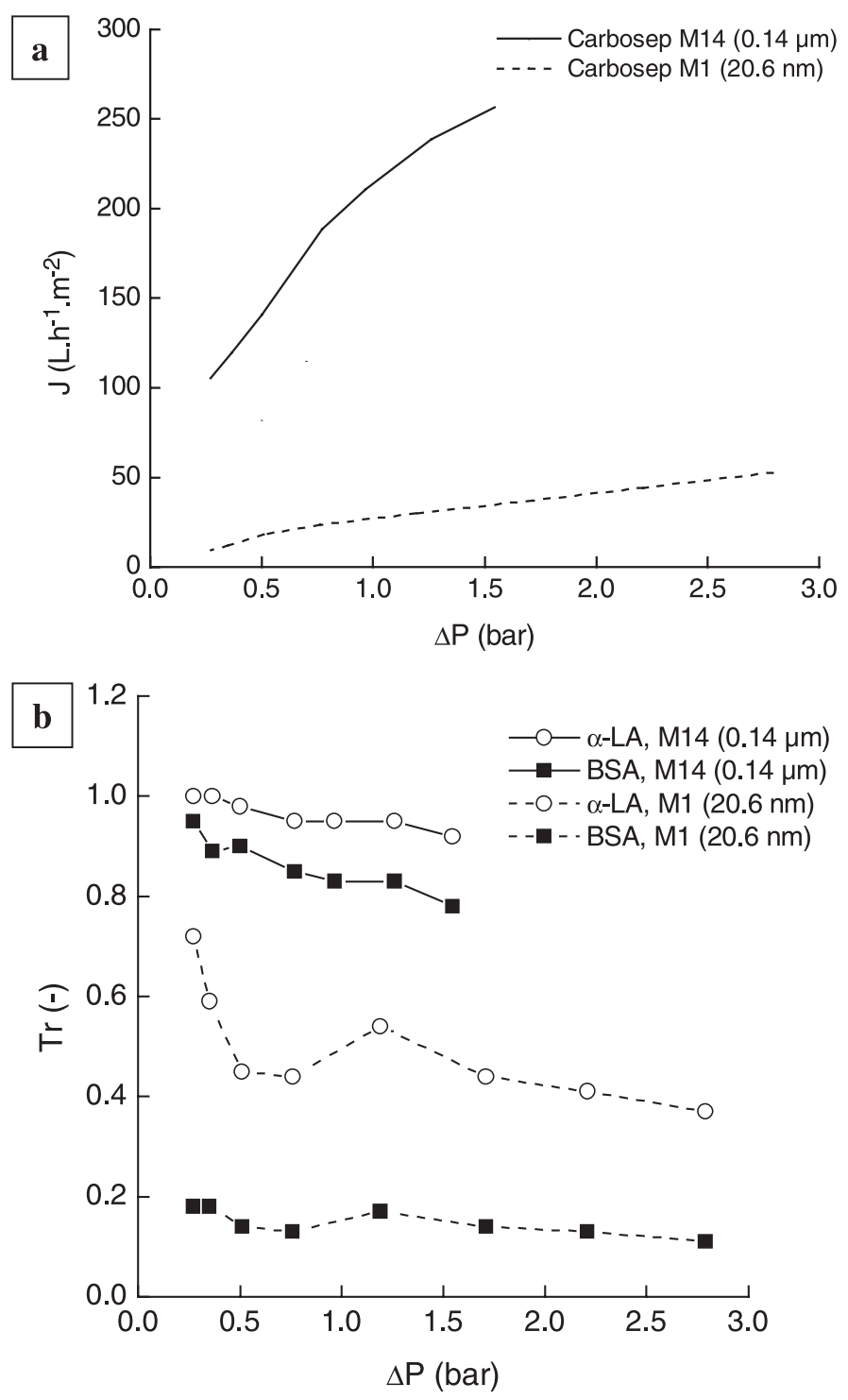

Figure 2. Influence of Carbosep membranes pore diameter/cut-off M14 (0.14 $\mu \mathrm{m})$, M1 (20.6 nm) on flux and retention of PS 90 powder vs. transmembrane pressure, $\Delta \mathrm{P}$. (a): evolution of flux, J. (b): protein transmission, Tr. Operating conditions: see Table II.

diameter, respectively, representing a larger pore size reduction of $33 \%$ for the UF membrane vs. $15 \%$ for the MF membrane.

The M1 membrane $(20.6 \mathrm{~nm}$; $150 \mathrm{~kg} \cdot \mathrm{mol}^{-1}$ ) was selected to study the influence of the next operating parameters, since it resulted in relatively high $\mathrm{Tr}$ of $\alpha$-LA and low, but not zero Tr of BSA, in order to be able to detect its variations with operating parameters. 
Further investigation into the relative influence of irreversible fouling and concentration polarisation on flux was done by running a successive increase and decrease in $\Delta \mathrm{P}$. The curve $\mathrm{J}$ vs. $\Delta \mathrm{P}$ showed a hysteresis (not shown). The analysis of the shape of the curves $J(\Delta P)$ and $R_{\mathrm{f}} / R_{\mathrm{m}}(\Delta \mathrm{P})$ (convex when $\Delta \mathrm{P}$ was increased, linear when $\Delta \mathrm{P}$ decreased) showed that $\mathrm{R}_{\mathrm{if}} / \mathrm{R}_{\mathrm{m}}$ had attained its maximum value at the highest $\Delta \mathrm{P}$. At the same time, $\mathrm{R}_{\mathrm{f}}$ increased with increased $\Delta \mathrm{P}$ but upon reduction of $\Delta \mathrm{P}$ it did not decrease at the same rate, which could have contributed to lower Tr. As a conclusion, an increase in $\Delta \mathrm{P}$ involved an increase in flux, which induced a significant increase in $R_{\text {if }}$ in such a way that concentration polarisation effects upon transmission were screened. Nonetheless, this conclusion should not be generalised, since the specific effects of $\mathrm{pH}$ and ionic strength on the relative contribution of irreversible fouling and concentration polarisation could not be neglected and their influence on $\operatorname{Tr}$ will be examined later.

The next set of experiments were aimed at studying the stability of UF performance at two different constant $\Delta \mathrm{P}, 1.0$ and 3.0 bar, for $4 \mathrm{~h}$ (Tab. II, 1). Steady J and $\mathrm{Tr}$ were observed after $2-3 \mathrm{~h}$. The higher $\Delta \mathrm{P}$ the lower $\operatorname{Tr}(\times 3$ lower $)$, the higher $\mathrm{J}$ and the higher $\frac{\mathrm{R}_{\mathrm{f}}}{\mathrm{R}_{\mathrm{m}}}(2.5$ at 1.0 bar, 4.9 at 3.0 bar). As was expected, owing to the UF time effect related to filtered volume, $R_{\text {if }}$ was higher and $\operatorname{Tr}$ was lower compared with obtained with $\mathrm{J}(\Delta \mathrm{P})$ cycle.

\subsubsection{Protein concentration}

UF was performed with two protein concentrations, 7 and $35 \mathrm{~g} \cdot \mathrm{L}^{-1}$, according to the $\mathrm{J}(\mathrm{Tr}, \Delta \mathrm{P})$ procedure (Tab. II, 2). Figure $3 \mathrm{a}$ shows $\mathrm{J}$ of about $10-20 \%$ higher with $7 \mathrm{~g} \cdot \mathrm{L}^{-1}$ over the whole $\Delta \mathrm{P}$ range (0.30-3.75 bar), with an irreversible fouling $\mathrm{R}_{\text {if }}$ of $1.1 \times 10^{13} \mathrm{~m}^{-1}$ and $1.6 \times 10^{13} \mathrm{~m}^{-1}$, respectively (irreversible fouling around $0.5 \times \mathrm{R}_{\mathrm{f}}$ ). At every $\Delta \mathrm{P}$ lower transmissions for $35 \mathrm{~g} \cdot \mathrm{L}^{-1}$ (Fig. $3 \mathrm{~b}$ ) were in good agree- ment with the classical influence of protein concentration upon UF performance, where transmission is probably governed more by irreversible fouling than by concentration polarisation. It should be noted that the lower $\operatorname{Tr}$ values obtained with BSA (close to 0 at $\Delta \mathrm{P}>3.0$ bar) at the higher protein concentration were beneficial for the purpose of this study of achieving a permeate with a higher purity of $\alpha$-LA, since they resulted in very low BSA concentration in the filtrate.

\subsubsection{Ionic strength}

UF runs were carried out with the varying $\Delta \mathrm{P}$ procedure with 3 ionic strengths: 0.0 , 0.2 and $1.0 \mathrm{~mol} \cdot \mathrm{L}^{-1}$ (Tab. II, 3). Figure 4 shows a decrease in protein transmissions $\left(\operatorname{Tr}_{\alpha-L A}\right.$ and $\left.\operatorname{Tr}_{\mathrm{BSA}}\right)$ as $\mathrm{J}$ increased due to $\Delta \mathrm{P}$ increase, whatever the I. The increase in $\mathrm{I}$ induced an increase in $\mathrm{J}$, which resulted from a decrease in $\mathrm{R}_{\mathrm{f}}$ and in particular in $\mathrm{R}_{\mathrm{if}}$ : $\frac{R_{\text {if }}}{R_{m}}$ was 6.2 at $\mathrm{I}=0.0 \mathrm{~mol} \cdot \mathrm{L}^{-1}$ and 3.0 at $\mathrm{I}=$ $1.0 \mathrm{~mol} \cdot \mathrm{L}^{-1}$. Decreased fouling coincided with decreased turbidity of the retentate feed at the different ionic strength levels with running time: $0.041,0.034$ and 0.003 absorbance units $\cdot \mathrm{h}^{-1}$ at $\mathrm{I}=0.0,0.2$ and $1.0 \mathrm{~mol} \cdot \mathrm{L}^{-1}$, respectively, which was in agreement with the general effect of ionic strength on protein stability. It may then be assumed that moderate protein participation in fouling was due to less protein denaturation at increased ionic strength.

At every ionic strength value, the observed experimental transmissions were lower than the transmission calculated according to Ferry's law, in spite of taking into account the average pore size of the irreversibly fouled membrane. Nonetheless, the higher the ionic strength, the lower the discrepancy between experimental transmission and calculated transmission. It is likely that at $\mathrm{pH} 7.0$ electrostatic repulsion between free protein and fouled membrane reduced charged protein transmission in good accordance with the model proposed by Rabiller-Baudry et al. [36] 

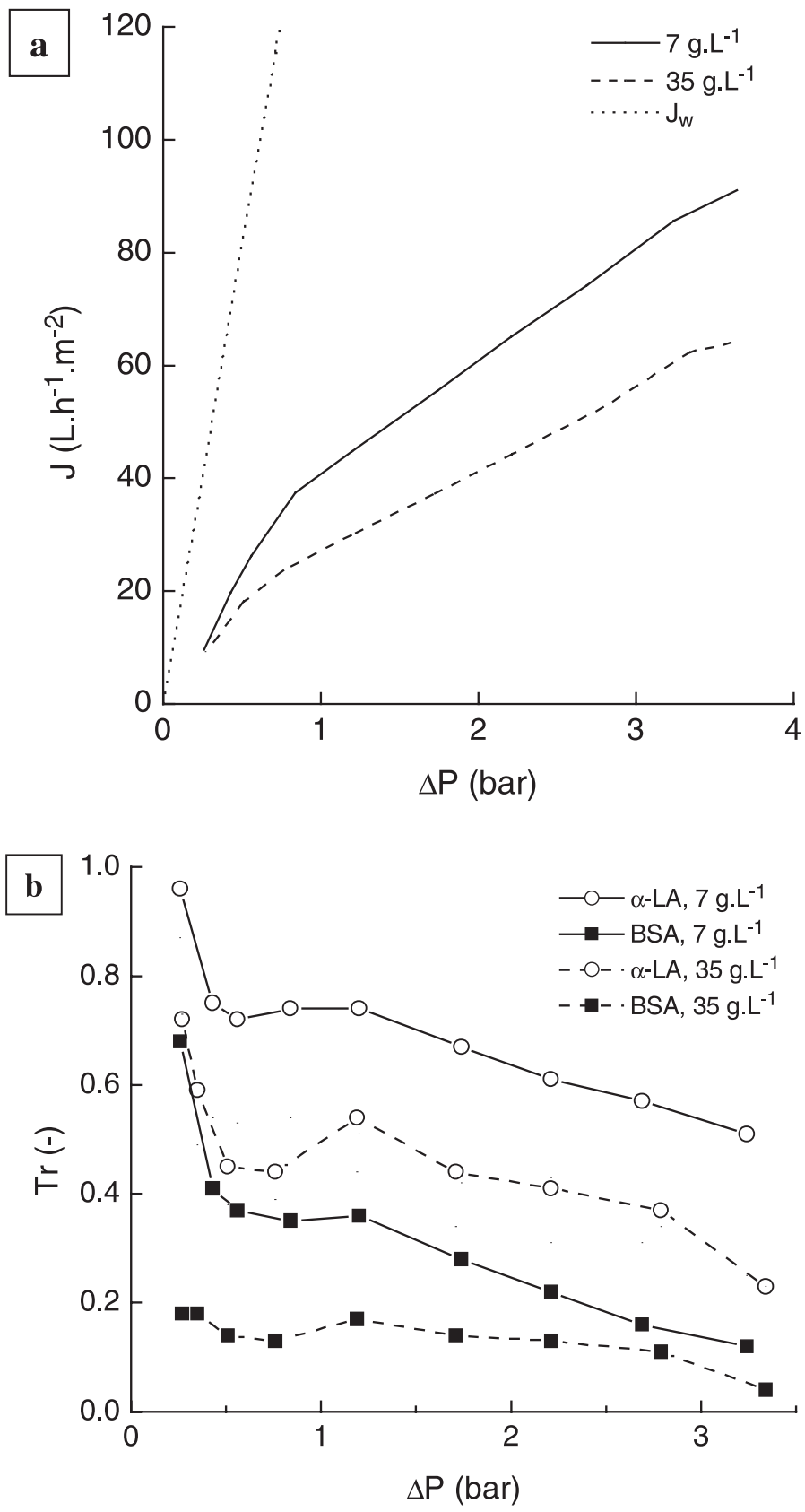

Figure 3. Influence of protein concentration with PS 90 powder on Carbosep M1 membrane performance vs. transmembrane pressure, $\Delta \mathrm{P}$. (a): evolution of flux, $\mathrm{J}$ and water flux, $\mathrm{J}_{\mathrm{w}}$. (b): protein transmission, Tr. Operating conditions: see Table II. 


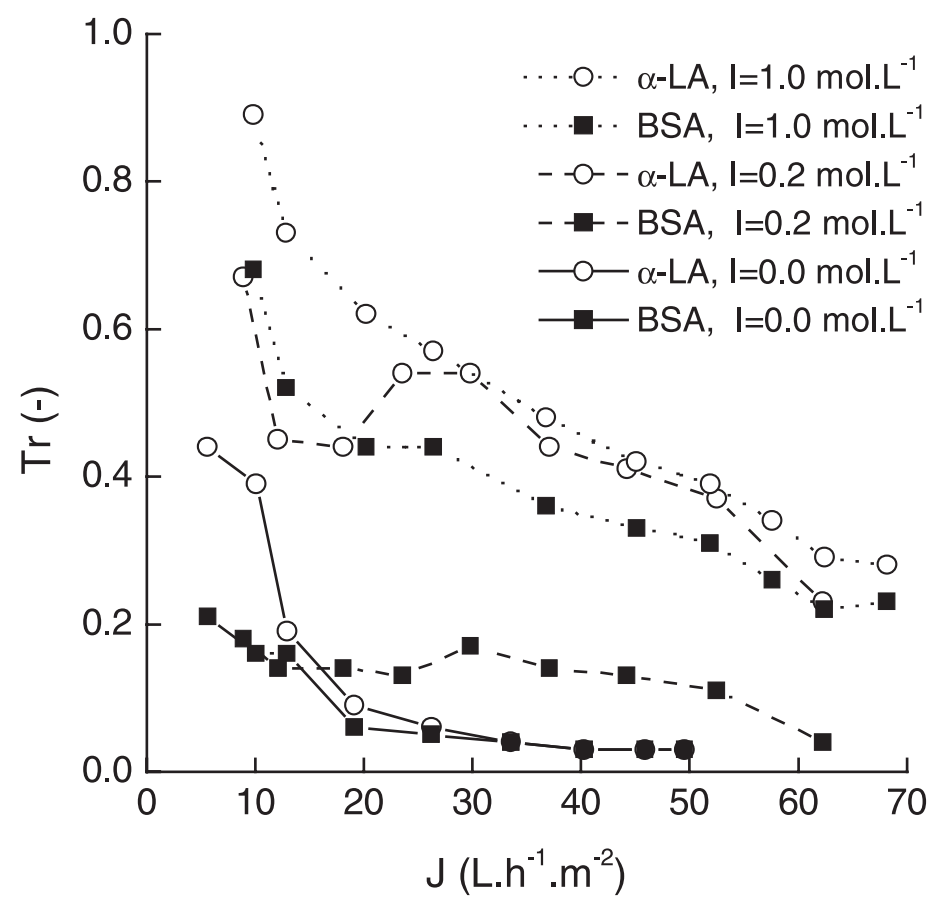

Figure 4. Influence of ionic strength on transmission ( $\mathrm{Tr}$ ) of $\alpha$-lactalbumin, $\alpha$-LA, and of bovine serum albumin, BSA, of PS 90 powder vs. flux of UF Carbosep M1 membrane $(20.6 \mathrm{~nm})$. Operating conditions: see Table II.

As a conclusion, the decrease in protein transmission with decreased I in the whole $\Delta \mathrm{P}$ range could be attributed to the decrease in protein concentration at the membrane wall due to: (i) the decrease in concentration polarisation, due to lower flux induced by higher irreversible fouling and (ii) weakened screening of the protein electrical charges by the electrolyte, $\mathrm{NaCl}$, in accordance with the explanation reported by Millesime et al. [29] and Lucas et al. [23, 24].

\subsection{4. pH and tangential flow velocity, $v$}

Table III presents the results observed for the 6 experiments carried out according to the experimental design. Among the numerous parameters calculated for quantifying the selectivity of the UF separation the only one which gave a significant statis- tical response was the difference of the maximum value for a single protein transmission, $\operatorname{Tr}_{\alpha \text {-LAMAX }}$ and the minimum one, $\operatorname{Tr}_{\text {Ig MIN }}$, appearing as $\Delta \operatorname{Tr}$. That criterion is relevant with regard to enhancing $\alpha$-LA purity provided transmission of IgG and BSA is decreased to 0 . The linear regression relating $\Delta \mathrm{Tr}$ to $\mathrm{pH}$ and $\mathrm{v}$ was:

$$
\Delta \mathrm{Tr}=0.38-0.10 \mathrm{pH}+0.15 \mathrm{v}
$$

with $\mathrm{R}^{2}=0.84$, significant Fisher test (risk $<5 \%$ ) and Student test significant for each regression coefficient.

The higher value of $\frac{\mathrm{R}_{\mathrm{f}}}{\mathrm{R}_{\mathrm{m}}}$ at $\mathrm{pH} 5.0$ was due to an increase in reversible fouling, $\frac{\mathrm{R}_{\mathrm{rf}}}{\mathrm{R}_{\mathrm{m}}}$, since irreversible fouling, $\frac{R_{i f}}{R_{m}}$ change was

not significant in the range $\mathrm{pH}-\mathrm{v}$ tested. The beneficial effect of an increase of $\mathrm{v}$ at this $\mathrm{pH} 5.0$ reinforced the assumption. 
Table III. Responses for the combinations $\mathrm{pH}-\mathrm{v}$ of the experimental design.

\begin{tabular}{|c|c|c|c|c|c|c|c|c|c|c|c|c|}
\hline \multirow{2}{*}{$\begin{array}{l}\mathrm{pH} \\
\mathrm{v} \\
\mathrm{m} \cdot \mathrm{s}^{-1}\end{array}$} & \multicolumn{4}{|c|}{5.0} & \multicolumn{4}{|c|}{6.0} & \multicolumn{4}{|c|}{7.0} \\
\hline & $\frac{R_{\mathrm{f}}}{\mathrm{R}_{\mathrm{m}}}$ & $\left(\frac{\mathrm{R}_{\mathrm{rf}}}{\mathrm{R}_{\mathrm{m}}}\right)$ & $\frac{\mathrm{R}_{\text {if }}}{\mathrm{R}_{\mathrm{m}}}$ & $\Delta \operatorname{Tr}$ & $\frac{R_{f}}{R_{m}}$ & $\left(\frac{\mathrm{R}_{\mathrm{rf}}}{\mathrm{R}_{\mathrm{m}}}\right)$ & $\frac{\mathrm{R}_{\text {if }}}{\mathrm{R}_{\mathrm{m}}}$ & $\Delta \operatorname{Tr}$ & $\frac{R_{f}}{R_{m}}$ & $\left(\frac{\mathrm{R}_{\mathrm{rf}}}{\mathrm{R}_{\mathrm{m}}}\right)$ & $\frac{\mathrm{R}_{\mathrm{if}}}{\mathrm{R}_{\mathrm{m}}}$ & $\Delta \operatorname{Tr}$ \\
\hline 2.0 & 12.6 & $(6.3)$ & 6.3 & 0.35 & & & & & 8.4 & $(4.7)$ & 3.7 & 0.10 \\
\hline & & & & & 12.2 & $(8.3)$ & 3.9 & 0.32 & & & & \\
\hline & & & & & 10.1 & $(3.7)$ & 6.4 & 0.52 & & & & \\
\hline 7.0 & 9.9 & (5.1) & 4.8 & 0.60 & & & & & 8.9 & (2.7) & 6.2 & 0.45 \\
\hline
\end{tabular}

$\mathrm{v}$ : flow velocity; $\mathrm{R}_{\mathrm{f}}=$ overall fouling hydraulic resistance; $\mathrm{R}_{\mathrm{if}}$ : irreversible fouling hydraulic resistance; $\mathrm{R}_{\mathrm{m}}$ : clean membrane hydraulic resistance; $\operatorname{Tr}$ : transmission; $\Delta \operatorname{Tr}=\operatorname{Tr}_{\alpha-\mathrm{LA} \mathrm{MAX}}-\operatorname{Tr}_{\mathrm{Ig}}$ MIN.

$* \frac{\mathrm{R}_{\mathrm{rf}}}{\mathrm{R}_{\mathrm{m}}}=\frac{\mathrm{R}_{\mathrm{f}}}{\mathrm{R}_{\mathrm{m}}}-\frac{\mathrm{R}_{\mathrm{if}}}{\mathrm{R}_{\mathrm{m}}}$. Operation conditions: see Table II.

Table IV. Physico-chemical characteristics of the major proteins of the WPC.

\begin{tabular}{lccccc}
\hline & & $\alpha-\mathrm{LA}$ & $\beta-\mathrm{LG}$ & $\mathrm{BSA}$ & $\operatorname{IgG}$ \\
\hline Molecular mass & $\mathrm{kg} \cdot \mathrm{mol}^{-1}$ & 14.2 & 36.6 & 67.0 & 150.0 \\
Stokes' radius & $\mathrm{nm}$ & 1.9 & 2.6 & 3.5 & 5.2 \\
Isoelectric $\mathrm{pH}$ & - & $4.2-4.5$ & $5.1-5.4$ & $4.8-5.1$ & $5.5-6.8 ; 7.5-8.3$ \\
\hline
\end{tabular}

$\alpha$-LA: $\alpha$-lactalbumin; $\beta$-LG: $\beta$-lactoglobulin; BSA: bovine serum albumin; IgG: immunoglobulin G.

Thus, at pH 5.0, a pH close to $\mathrm{pI}$ of most of the whey proteins (Tab. IV), the prominent phenomena were probably, (i) maximum adsorbed protein amount [10]; (ii) preferential aggregation of the proteins at this $\mathrm{pH}$ [30], which could be responsible for the increase in both $\mathrm{R}_{\mathrm{rf}}$ and $\mathrm{R}_{\mathrm{if}}$; and (iii) minimum mass transfer coefficient due to minimum diffusion coefficient [39].

At pH 7.0 and low ionic strength, electrostatic repulsion between the negatively charged proteins adsorbed on the membrane and the negatively charged proteins in the bulk could well explain the lower value of $\Delta \mathrm{Tr}$.

Thus, $\mathrm{pH}=7.0$ and $\mathrm{v}=7.0 \mathrm{~m} \cdot \mathrm{s}^{-1}$ were the conditions selected for limiting fouling $\left(\mathrm{R}_{\mathrm{rf}}\right.$ and $\left.\mathrm{R}_{\mathrm{if}}\right)$ and for increasing $\Delta \mathrm{Tr}$.

\subsection{Operation for the prepurification of $\alpha$-lactalbumin}

To continue the adjustments and checking of the operating parameters needed to achieve the objective of high purity $\alpha$-LA in the permeate of the membrane operation, it was decided to operate UF with an increasing volume concentration ratio and a product as close as possible to the natural whey.

\subsubsection{Membrane selection}

The objective was to adjust the membrane average pore size so as to get $\operatorname{Tr}_{\mathrm{BSA}}$ and $\operatorname{Tr}_{\mathrm{IgG}}$ as close to 0 as possible and enhanced $\alpha$-LA purity in the permeate. With the M1 membrane the transmissions 


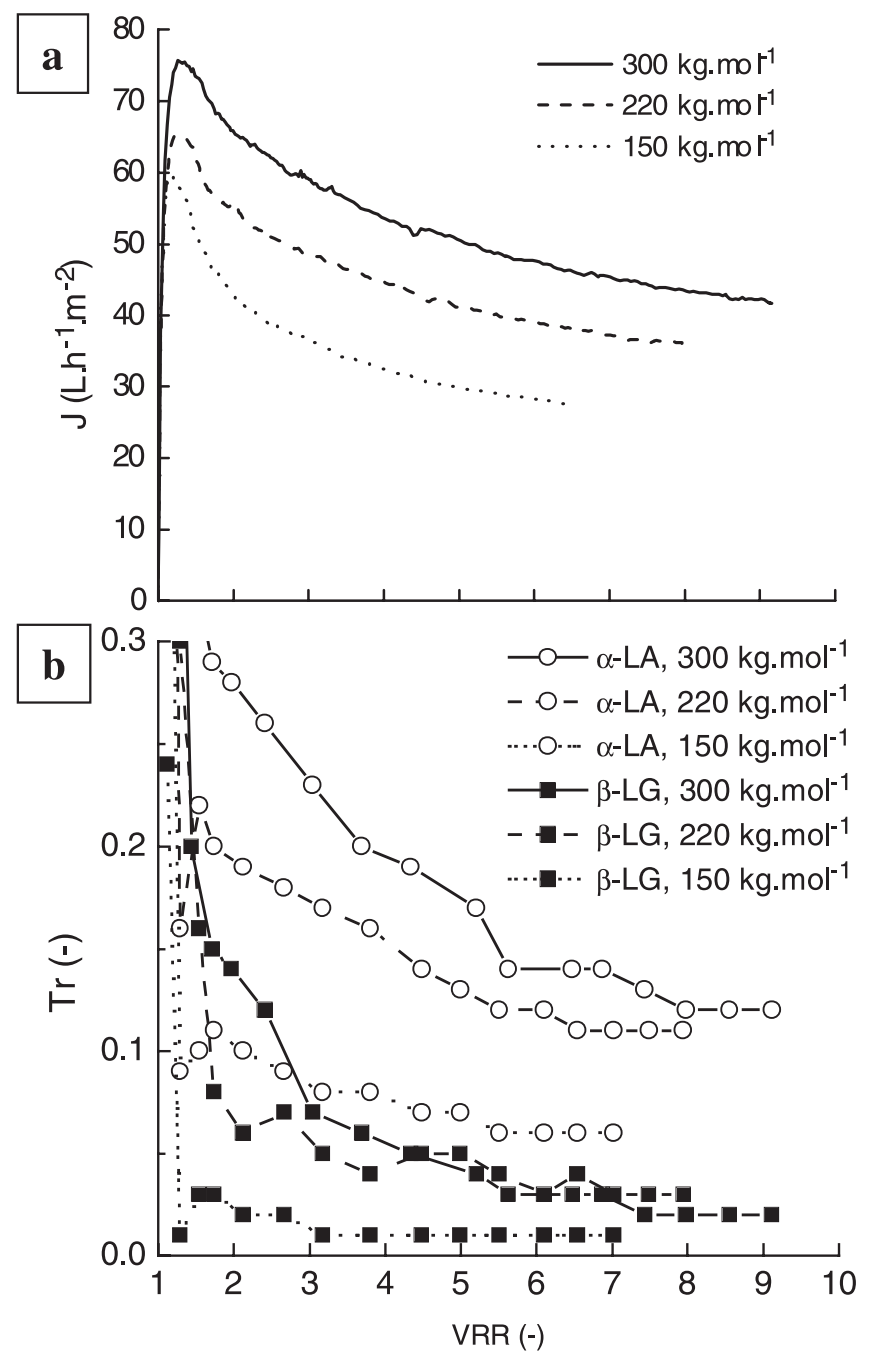

Figure 5. Performances of Céram UF membranes $\left(300 \mathrm{~kg} \cdot \mathrm{mol}^{-1}, 220 \mathrm{~kg} \cdot \mathrm{mol}^{-1}, 150 \mathrm{~kg} \cdot \mathrm{mol}^{-1}\right)$ with clarified PS 90 powder vs. volume reduction ratio, VRR (continuous concentration mode). (a): evolution of flux, J. (b): transmission (Tr) of $\alpha$-lactalbumin and $\beta$-lactoglobulin. Operating conditions: see Table II.

of the proteins to be retained were too high, $\operatorname{Tr}_{\mathrm{BSA}}$ and $\operatorname{Tr}_{\mathrm{IgG}}=0.10$, to achieve a filtrate containing $\alpha$-LA and $\beta$-LG only. Thus, the M1 membrane was rejected for runs operating at increasing VRR. Céram membranes of 300,220 and $150 \mathrm{~kg} \cdot \mathrm{mol}^{-1} \mathrm{MMCO}$ were compared using $7 \mathrm{~g} \cdot \mathrm{L}^{-1}$ PS 90 powder (Tab. II, 5). In this part of the work, UF was performed with the system of uniform transmembrane pressure (permeate circulation co-current to retentate), since $\mathrm{Tr}$ depended on $\Delta \mathrm{P}$.

Permeation flux, higher with larger MMCO, decreased with increasing VRR (Fig. 5a). From around VRR 3 (1 h UF), $\operatorname{Tr}_{\mathrm{BSA}}$ and $\operatorname{Tr}_{\mathrm{IgG}}$ were $<0.005$ for the three 
Table V. Comparison of performance of the 3 Céram membranes at increasing volume concentration ratio for $4 \mathrm{~h}$ (PS 90 powder).

\begin{tabular}{lccc}
\hline $\begin{array}{l}\text { Membrane MMCO } \\
\mathrm{kg} \cdot \mathrm{mol}^{-1}\end{array}$ & 150 & 220 & 300 \\
\hline $\mathrm{J}_{\mathrm{AV}}\left(\mathrm{L} \cdot \mathrm{h}^{-1} \cdot \mathrm{m}^{-2}\right)$ & 50.3 & 43.1 & 33.9 \\
$\mathrm{P}_{\mathrm{ps}}(-)$ & $>0.995$ & $>0.995$ & $>0.995$ \\
$\mathrm{P}_{\mathrm{p} \alpha-\mathrm{LA}}$ & 0.44 & 0.29 & 0.33 \\
$\mathrm{Y}_{\mathrm{p} \alpha-\mathrm{LA}}(-)$ & 0.16 & 0.31 & 0.4 \\
$\mathrm{C}_{\mathrm{p} \alpha-\mathrm{LA}}\left(\mathrm{g} \cdot \mathrm{L}^{-1}\right)$ & 0.5 & 1.3 & 1.5 \\
\hline
\end{tabular}

C: concentration; $\mathrm{J}_{\mathrm{AV}}$ : average flux; P: purity; p: permeate; s: small proteins; $\mathrm{Y}$ : yield.

membranes. $\alpha$-LA and $\beta$-LG transmissions decreased with VRR and time (Fig. 5b). Above VRR 4, $\operatorname{Tr}_{\beta-L G}$ was similar for the 300 and $220 \mathrm{~kg} \cdot \mathrm{mol}^{-1} \mathrm{MMCO}$ membranes. Flux and transmission were quite steady at VRR around 6 (Figs. 5a, b). $\mathrm{R}_{\text {if }}$ was higher $\left(15.9 \times 10^{12} \mathrm{~m}^{-1}\right)$ and constituted the major part $(95 \%)$ of $\mathrm{R}_{\mathrm{f}}$ for the smallest MMCO, $150 \mathrm{~kg} \cdot \mathrm{mol}^{-1}$. This, combined with the smaller pore size, provided the lowest $\operatorname{Tr}_{\alpha \text {-LA }}(0.05)$ and $\operatorname{Tr}_{\beta-L G}(0.02)$ observed with this membrane, which showed the highest $\alpha$-LA purity (0.44) along with the lowest $\alpha$-LA yield (0.16).

Therefore, the $300 \mathrm{~kg} \cdot \mathrm{mol}^{-1}$ membrane was selected as the most appropriate membrane because it showed both satisfactory purity (0.33) and yield (0.40) for $\alpha$-LA (Tab. V). Purity, $\mathrm{P}_{\mathrm{p} \alpha-\mathrm{LA}}$, was 0.33 only but it was 1.7 times higher than the initial purity, $\mathrm{P}_{\mathrm{i}} 0.14$. The higher $\mathrm{Y}_{\mathrm{p} \alpha-\mathrm{LA}}$ (due to higher $\left.\operatorname{Tr}_{\alpha-\mathrm{LA}}\right)$ associated with higher $\mathrm{J}$ allowed the recovery of larger amounts of $\alpha$-LA in the permeate for a given UF time.

\subsubsection{Feed selection}

A set of experiments was performed with 3 feeds at the same initial total protein concentration $\left(7 \mathrm{~g} \cdot \mathrm{L}^{-1}\right)$.

Similar evolution of flux vs. time was observed with the 3 feeds: slow decline from $95-75$ to $60-40 \mathrm{~L} \cdot \mathrm{h}^{-1} \cdot \mathrm{m}^{-2}$ (Fig. 6a); $\mathrm{J}$ was around 1.3 times higher with PS 90 liquid: average $\mathbf{J}$ was $64.1,49.8$ and $48.4 \mathrm{~L} \cdot \mathrm{h}^{-1} \cdot \mathrm{m}^{-2}$ for PS 90 liquid, PS 75 liquid and PS 90 powder, respectively. Final VRR after $4 \mathrm{~h}$ UF ranged from 8.7 to 11.2 , depending on the feed. For PS 90 liquid the fouling resistance $R_{f}$ was around 2 times lower than that of the other 2 feeds, with $R_{\text {if }}\left(0.45 \times R_{f}\right)$ lower than for PS 90 powder and for PS $75\left(0.6 \times \mathrm{R}_{\mathrm{f}}\right)$. These results are consistent with a lower turbidity of PS 90 liquid and explain the higher flux and lower fouling, which were related to protein stability: PS 90 liquid resulted in $\mathrm{OD}_{600}=0.16$ after $3.5 \mathrm{~h}$ UF compared with 0.30 with PS 90 powder and 1.20 with PS 75. This was due to the manufacturing process of PS 90, which included a clarification-microfiltration step, aimed at removing residual fat, calcium phosphates and other insoluble matter such as denatured proteins, with an extra final spray drying for PS 90 powder (Tab. I). It is also likely that insoluble material present in PS 75 and concentrated during UF was the cause of higher fouling, lower flux and lower transmissions. As for PS 90 powder, WPC originating from PS 75 liquid, it did not contain insolubles (compared with PS 75) but spray drying had sensitised the proteins. The HPLC profiles (Fig. 1) confirm these assumptions regarding protein denaturation, through slightly increased retention time according to PS 90 powder > PS 90 liquid > PS 75 liquid. This explains why PS 90 powder was prone to fouling the membrane, preferentially within the pores since both flux and transmission were lower compared with PS 90 liquid. 


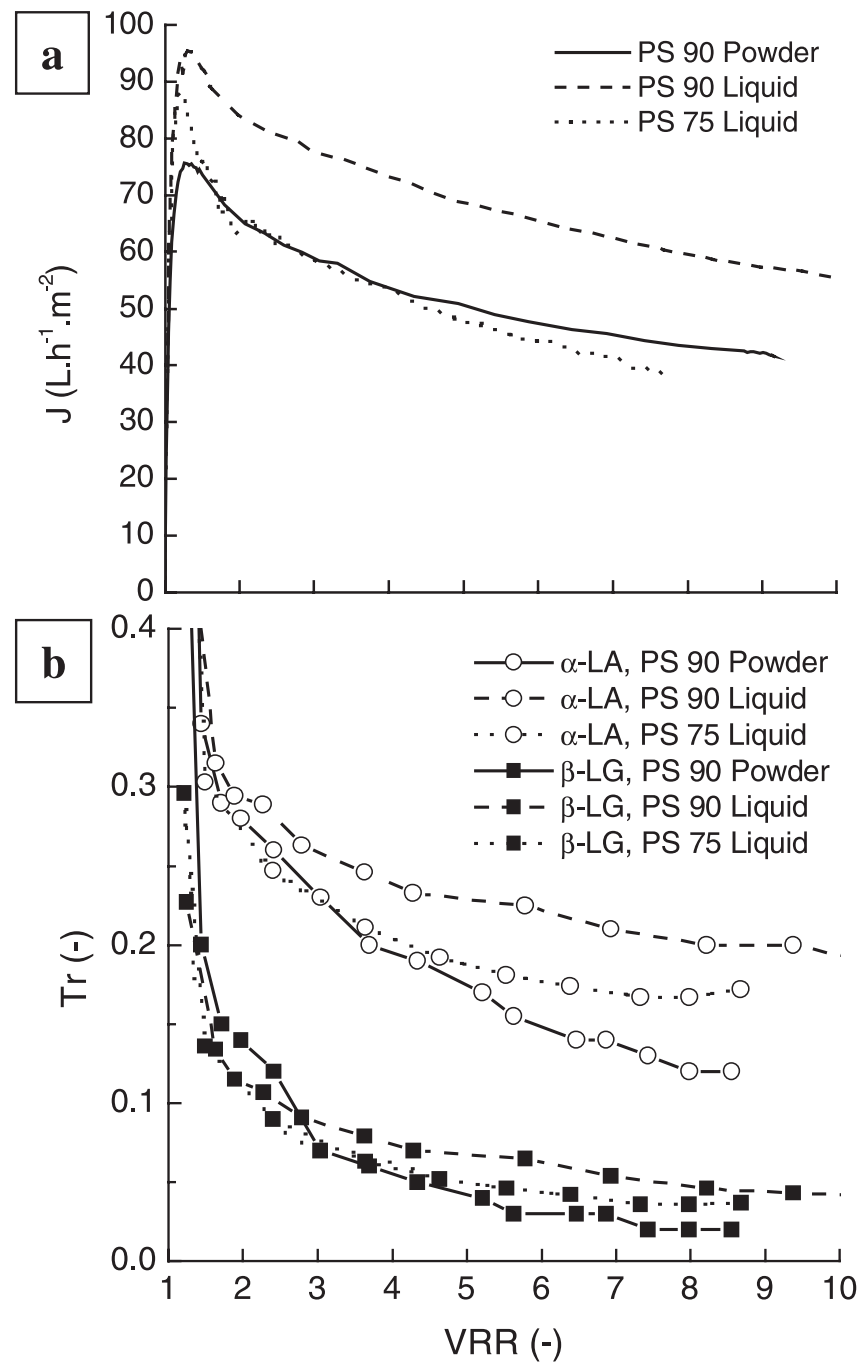

Figure 6. Performances of Céram UF membranes $\left(300 \mathrm{~kg} \cdot \mathrm{mol}^{-1}\right)$ with 3 different PS feeds $\left(7 \mathrm{~g} \cdot \mathrm{L}^{-1}\right)$ vs. volume reduction ratio, VRR. (a): evolution of flux (J). (b): transmission (Tr) of $\alpha-L A$ and $\beta$-LG. Operating conditions: see Table II.

The transmission of BSA and IgG were less than 0.005 after $2 \mathrm{~h} \mathrm{UF}$ (VRR 5-6) with all the feeds, while $\operatorname{Tr}_{\alpha-L A}$ and $\operatorname{Tr}_{\beta-L G}$ varied a little with feed. Quasi-stationary transmissions at the end of the runs were in the range $0.12-0.19$ for $\alpha$-LA and $0.02-$ 0.05 for $\beta$-LG with higher values for PS 90 liquid (Fig. 6b).
$\alpha$-LA purity increased in the whole permeate collected from VRR 1 to VRR 9: 0.44 vs. 0.25 initially (PS 90 liquid), 0.33 vs. 0.14 (PS 90 powder) and 0.37 vs. 0.17 (PS 75). Clearly, with PS 90 liquid, better purity of $\alpha$-LA was achieved in spite of higher $\beta-\mathrm{LG}$ transmission. Finally, the highest flux and $\operatorname{Tr}_{\alpha \text {-LA }}$ with PS 90 liquid 
favoured a higher yield: 0.53 vs. $0.40-0.42$ with the other 2 feeds.

\subsection{Proposal of operating conditions for prepurifying $\alpha-L A$}

The outcome of the present experimental work was that the priority targets of the fractionation process were achieved with the continuous concentration UF mode operating as follows: $300 \mathrm{~kg} \cdot \mathrm{mol}^{-1}$ Céram membrane, clarified PS 90 liquid (initial $\left.\mathrm{P}_{\alpha-\mathrm{LA}}=0.25\right), \mathrm{C}=7 \mathrm{~g} \cdot \mathrm{L}^{-1} ; \mathrm{pH}=7.0 ; \mathrm{I}=$ $0.2 \mathrm{~mol} \cdot \mathrm{L}^{-1}$; dynamic counter pressure, $\Delta \mathrm{P}=1.0$ bar; $\mathrm{v}=6 \mathrm{~m} \cdot \mathrm{s}^{-1} ; \mathrm{T}=50^{\circ} \mathrm{C}$.

Nonetheless, those particular conditions only constitute a general guideline, since the proper operation conditions will have to be adjusted as a function of the industrial feed characteristics, including its thermal and mechanical history:

- according to the flow sheet of the manufacturing process of PS 90 liquid, after clarification, the fractionation step was the 6th one (Tab. I). During the first 2 UF and 2 diafiltration steps performed at the factory, $\mathrm{P}_{\alpha-\mathrm{LA}}$ decreased due to small $\alpha$-LA leakage. Thus, a novel flow-sheet with only a few filtration steps should be proposed to limit losses of $\alpha$-LA and heat and mechanical denaturation: clarificationmicrofiltration (removal of residual fat, insolubles), ultrafiltration (protein concentration adjustment), and diafiltration (removal of lactose, ions, peptides, etc.) with water of a proper ionic strength (around $0.2 \mathrm{~mol} \cdot \mathrm{L}^{-1} \mathrm{NaCl}$ ). The latter should be just high enough so as to ensure limited fouling, higher transmission and no protein denaturation without increasing the salt content of the final $\alpha$-LA fraction too much. Nevertheless, the source of whey in the present study is not the only one for $\alpha$-LA fractionation. It is possible to obtain native $\alpha$-LA from milk microfiltrate with no GMP, and from sweet whey with GMP. Acid casein whey will produce the A-state $\alpha$-LA and also without GMP. These streams should be considered when aiming at producing high purity $\alpha$-LA with such a structure that the target function is preserved from the nutritional as well as the biological point of view;

- the selectivity of the separation of two proteins (BSA and $\operatorname{IgG}$ ) depends on the combination crossflow velocity-flux, with different laws according to the flow regime [13];

- the volume reduction ratio obtained in our experiments was close to 11 . With the continuous concentration mode it is likely that an optimal VRR could be achieved [31], which represents a good compromise between $\alpha$-LA concentration in the permeate (which depends on retentate $\alpha$-LA concentration) and fouling so as not to alter $\alpha$-LA transmission and flux. A cascade of two steps, ultrafiltration ( $\alpha$-LA fractionation and purification)-diafiltration (increased $\alpha$-LA yield) with the feed and bleed mode would probably be the best performing processing mode [30];

- various phenomena involved in some of the above observations, such as low ionic strength or high retentate protein concentration would cause greater irreversible fouling. These will result in the necessity of readjusting the MMCO of the membrane so as to take into account the variations of protein transmission with the pore size reduction, due to fouling. Muller [30] reported that in a range of pore sizes in which transmission of contaminating proteins (Ig, BSA and the major protein in WPC, $\beta-\mathrm{LG}$ ) exceeds a few hundredths, a sharp decrease of $\alpha$-LA purity in the permeate is to be expected. Thus, membrane and pore size must be tailor-made for each particular whey or WPC in order to comply with the target of the fractionation with this fouled membrane, which is obtaining a permeate enriched in $\alpha$-LA and depleted of any other whey proteins. Such a permeate will be an interesting feed for achieving a high purity $\alpha$-LA fraction through a 2nd step consisting of either $\alpha$-LA aggregation $[4,30]$ or UF [30] or of alternative processes such as ion exchange $[6,49]$ in order to separate $\alpha$-LA and $\beta$-LG. 
It is noteworthy that the retentate of this operation is a co-product with high added value due to its composition: around $65 \mathrm{~g} \cdot \mathrm{L}^{-1}$ protein with $0.95 \beta$-LG purity and $0.04 \alpha$-LA purity, which corresponds to a whey protein isolate 99 [46].

\section{CONCLUSIONS}

The variations in physico-chemical and hydrodynamic operating conditions led to large variation in protein transmission in a range of 0.6-0.7 and to a decrease in BSA transmission with a low decrease in $\operatorname{Tr}_{\alpha \text {-LA }}$ (around 0.2) for the target separation. The prominent role of irreversible fouling over that of concentration polarisation on the transmissions was highlighted: an increase in irreversible fouling, $R_{i f}$, induced a decrease in every protein transmission, and generally in an increase in $\alpha$-LA purity in the filtrate. Fouling was mainly sensitive to variation of concentration polarisation (related to protein concentration, transmembrane pressure, and tangential flow velocity) and to protein denaturation while filtering. To limit it, a low transmembrane pressure (1-2 bar, i.e. low flux, around $30 \mathrm{~L} \cdot \mathrm{h}^{-1} \cdot \mathrm{m}^{-2}$ ) was adequate. Electrostatic interactions that varied with both ionic strength and $\mathrm{pH}$ participated in both irreversible fouling and separation performances, and should be mastered so as to yield the best compromise: more lowered transmission for $\operatorname{IgG}$ and BSA than for $\alpha$-LA.

Enhanced $\alpha$-lactalbumin purity (0.44) and satisfactory yield $(0.53)$ was achieved with a continuous UF concentration mode $(\mathrm{VRR}=9)$ owing to a proper selection of average membrane pore size (no BSA and IgG transmission) and of operating conditions so as to limit fouling and to ensure a satisfactory transmission of $\alpha$-LA while limiting transmission of $\beta$-LG. Enhanced performances could certainly result from adapting processing conditions during the preparation of the whey protein source with the major objective of preserving native properties of whey proteins.

\section{List of abbreviations:}

$\mathrm{C}$ : concentration; $\mathrm{Cp}$ : protein concentration in the permeate $\left(\mathrm{g} \cdot \mathrm{L}^{-1}\right)$; Cr: protein concentration in the retentate $\left(\mathrm{g} \cdot \mathrm{L}^{-1}\right)$; $\mathrm{I}$ : ionic strength $\left(\mathrm{mol} \cdot \mathrm{L}^{-1}\right)$; J: permeate flux $\left(\mathrm{L} \cdot \mathrm{h}^{-1} \cdot \mathrm{m}^{-2}\right)$; MM: molecular mass $\left(\mathrm{kg} \cdot \mathrm{mol}^{-1}\right)$; MMCO: molecular mass cutoff $\left(\mathrm{kg} \cdot \mathrm{mol}^{-1}\right) ; \quad$ OD: optical density (absorbance units, -); P: protein purity (-); $\mathrm{R}_{\mathrm{f}}$ : overall fouling hydraulic resistance $\left(\mathrm{m}^{-1}\right) ; \mathrm{R}_{\mathrm{if}}$ : irreversible fouling hydraulic resistance $\left(\mathrm{m}^{-1}\right) ; \mathrm{R}_{\mathrm{m}}$ : membrane hydraulic resistance $\left(\mathrm{m}^{-1}\right) ; \mathrm{r}_{\mathrm{p}}=$ pore radius $(\mathrm{nm})$; $r_{p f}=$ fouled pore radius $(\mathrm{nm}) ; r_{\mathrm{s}}=$ Stokes radius $(\mathrm{nm}) ; \quad \mathrm{R}_{\mathrm{rf}}$ : reversible fouling hydraulic resistance $\left(\mathrm{m}^{-1}\right)$; T: temperature $\left({ }^{\circ} \mathrm{C}\right)$; $\mathrm{Tr}$ : transmission (-); v: crossflow velocity $\left(\mathrm{m} \cdot \mathrm{s}^{-1}\right)$; VRR: volume reduction ratio (-); Y: yield (-); $\Delta \mathrm{P}$ : transmembrane pressure (bar); $\lambda$ : ratio of Stokes radius to pore size; $\tau_{\omega}$ : wall shear stress $(\mathrm{Pa})$.

\section{ACKNOWLEDGEMENT}

This work was supported within the framework of a European Commission subsidised project (AIR 2 - CT 93 - 1207).

\section{REFERENCES}

[1] Blazey N.D., Knights R.J., Wu C., Membrane filtered milk proteins varying in composition and functional properties, Int. Patent Appl. PCT WO 00/51440, 2000.

[2] Bottomley R.C., Process for obtaining concentrates having a high $\alpha$-lactalbumin content from whey, Eur. Patent Appl. EP 0 311283 A2, 1989.

[3] Bramaud C., Optimisation of a fractionation process of whey proteins including selective precipitation and membrane separation, Ph.D. Thesis, Univ. P. Sabatier, Toulouse, France, 1995.

[4] Bramaud C., Aimar P., Daufin G., Optimisation of a whey protein fractionation process based on the selective precipitation of $\alpha$-lactalbumin, Lait 77 (1997) 411-423.

[5] Brew K., Grobler J.A., $\alpha$-Lactalbumin, in: Fox P.F. (Ed.), Advanced Dairy Chemistry 1: Proteins, Elsevier Applied Science, London, UK, 1992, pp. 191-229. 
[6] Couriol C., Le Quellec S., Guihard L., Mollé D., Chaufer B., Prigent Y., Separation of acid whey proteins on the preparative scale by hyperdiffusive anion exchange chromatography, Chromatographia $52 \quad$ (2000) 456-472.

[7] Daufin G., Radenac J.F., Gésan G., Kerhervé F.L., Le Berre O., Michel F., Merin U., A novel rig design for ultra and microfiltration for experiments, Separ. Sci. Technol. 28 (1993) 2635-2642.

[8] de la Fuente M.A., Hemar Y., Tamehama M., Munro P.A., Singh H., Process-induced changes in whey proteins during the manufacture of whey protein concentrates, Int. Dairy J. 12 (2002) 361-369.

[9] de Wit J.N., Bronts H., Process for the recovery of $\alpha$-lactalbumin and $\beta$-lactoglobulin from a whey protein product, Eur. Patent Appl. EP 0604684 A1, 1994.

[10] Fane A.G., Fell C.J.D., Waters A.G., Ultrafiltration of protein solutions through partially permeable membranes - the effect of adsorption and solution environment, $\mathrm{J}$. Membrane Sci. 16 (1983) 211-224.

[11] Ferry J.D., Ultrafilter membranes and ultrafiltration, Chem. Rev. 18 (1936) 373-455.

[12] Gésan G., Daufin G., Merin U., Labbé J.P., Quémerais A., Fouling during constant flux crossflow microfiltration of pretreated whey. Influence of transmembrane pressure gradient, J. Membrane Sci. 80 (1993) $131-145$.

[13] Ghosh R., Cui Z.F., Simulation study of the fractionation of proteins using ultrafiltration, J. Membrane Sci. 180 (2000) 29-36.

[14] Hakansson A., Zhivotorsky B., Orrenius S., Sabharwal H., Svanborg C., Apoptosis induced by a human milk protein, Proc. Natl. Acad. Sci. 92 (1995) 8064.

[15] Hambraeus L., Importance of milk proteins in human nutrition: physiological aspects, in: Galesloot T.E., Tinbergen B.J. (Eds.), Milk protein '84, Pudoc Wageningen, The Netherlands, 1984, pp. 63-79.

[16] Harang B., Uses of compositions with $\alpha$-lactalbumin base, Int. Patent Appl. PCT WO 98/14204, 1998.

[17] Hirai Y., Permiakov E.A., Berliner L.J., Proteolytic digestion of $\alpha$-lactalbumin: physiological implications, J. Protein Chem. 11 (1992) 51.

[18] IDF, World Dairy Situation 1999, Bull. Int Dairy Fed., Brussels, Belgium, 339, 1999.

[19] Jensen J., Larsen P.H., Method for obtaining high-quality protein products from whey, Int. Patent Appl. PCT WO 93/21781, 1993.
[20] Kinsella J.E., Whitehead D.M., Proteins in whey: chemical, physical and functional properties, in: Kinsella J.E. (Ed.), Advances in Food and Nutrition Research, Academic Press, Harcourt Brace, Jovanovich Publishers, San Diego, USA, 1989, pp. 343-348.

[21] Kronman M.J., Metal-ion binding and molecular conformational properties of $\alpha$-lactalbumin. An overview, CRC Crit. Rev. Biochem. Mol. Biol. 24 (1989) 565-667.

[22] Li J., Zhang S., Wang C., Only the reduced conformer of $\alpha$-lactalbumin is inducible to aggregation by protein aggregates, J. Biochem. 129 (2001) 821-826.

[23] Lucas D., Rabiller-Baudry M., Michel F., Chaufer B., Role of the physicochemical environment on ultrafiltration of lysozyme with modified inorganic membrane, Colloid Surface A 136 (1998) 109-122.

[24] Lucas D., Rabiller-Baudry M., Millesime L., Chaufer B., Daufin G., Extraction of $\alpha$-lactalbumin from whey protein concentrate with modified inorganic membranes, J. Membrane Sci. 148 (1998) 1-12.

[25] Mailliart P., Ribadeau-Dumas B., Preparation of $\beta$-lactoglobulin and $\alpha$-lactalbumin-free proteins from whey retentate by $\mathrm{NaCl}$ salting out a low pH, J. Food Sci. 53 (1988) 743-752.

[26] Marshall K.R., Industrial isolation of milk proteins: whey proteins, in: Fox P.F. (Ed.), Developments in Dairy Chemistry - 1: Dairy Products - Analysis and Examination Periodicals, Applied Science Publishing, New York, USA, 1982, pp. 339-367.

[27] Marwaha S.S., Kennedy J.F., Review: whey-pollution problem and potential utilisation, Int. J. Food Sci. Technol. 23 (1988) 323-336.

[28] Matsumoto H., Shimokawa Y., Ushida Y., Toida T., Hayasawa H., New biological fonction of bovine $\alpha$-lactalbumin: protective effect against ethanol and stress-induced gastric mucosal impury in rats, Biotechnol. Biochem. 65 (2001) 1104-1111.

[29] Millesime L., Dulieu J., Chaufer B., Protein retention with modified and unmodified inorganic ultrafiltration membranes: model of ionic strength controlled retention, J. Membrane Sci. 108 (1995) 143-159.

[30] Muller A., Process for obtaining high purity $\alpha$-lactalbumin: elementary steps of whey proteins fractionation and cascade set-up, Ph.D. Thesis, ENSA Rennes, France, 1996.

[31] Muller A., Daufin G., Chaufer B., Ultrafiltration modes of operation for the separation of $\alpha$-lactalbumin from acid casein whey, J. Membrane Sci. 153 (1999) 9-21. 
[32] Outinen M., Harju M., Tossavainen O., Antila P., Process for fractionating whey proteins and the components obtained, Int. Patent Appl. PCT WO 95/19714, 1995.

[33] Pearce R.J., Thermal separation of $\beta$-lactoglobulin and $\alpha$-lactalbumin in bovine Cheddar cheese whey, Aust. J. Dairy Technol. 38 (1983) 144-148.

[34] Pearce R.J., Whey protein fractions, Int. PatentAppl.PCTWO88/06673,1988.

[35] Pierre A., Fauquant J., Principles for an industrial process for the fractionation of whey protein, Lait 66 (1986) 405-419.

[36] Rabiller-Baudry M., Chaufer B., Aimar P., Bariou B., Lucas D., Application of a convection-diffusion-electrophoretic migration model to ultrafiltration of lysozyme at different $\mathrm{pH}$ values and ionic strengths, J. Membrane Sci. 179 (2000) 163-174.

[37] Roger L., Maubois J.-L., Brulé G., Piot M., Product enriched in $\alpha$-lactalbumin. Obtention from whey and applications of the product, Fr. Patent Appl. FR 7916 482, 1979.

[38] Roger L., Maubois J.-L., Brulé G., Piot M., Process for obtaining an $\alpha$-lactalbumin enriched product from whey, and uses thereof, U.S. Patent Appl. 4.485.040, 1984.

[39] Saksena S., Zydney A.L., Effect of solution $\mathrm{pH}$ and ionic strength on the separation of albumin from immunoglobulins ( $\mathrm{IgG}$ ) by selective filtration, Biotechnol. Bioeng. 43 (1994) 960-968.

[40] Shimatani M., Uchida Y., Matsuno I., Sugawara M., Nakano T., Process for the manufacture of a composition with a high alactalbumin content, Fr. Patent Appl. FR 2 $671697,1992$.
[41] Shur B.D., $\alpha$-Lactalbumin contraceptive, Int. Patent Appl. PCT WO 84/04457, 1984.

[42] Stack F.M., Hennessy M., Mulvihill D., O'Kennedy B.T., Process for the fractionation of whey constituents, Int Patent Appl. PCT WO 95/34216, 1995.

[43] Svensson M., Hakansson A., Mossberg A.K., Linse S., Svanborg C., Conversion of $\alpha$-lactalbumin to a protein inducing apoptosis, Proc. Natl. Acad. Sci. 97 (2000) 4221-4226.

[44] Taddéi C., Daufin G., Aimar P., Sanchez V., Role of some whey components on the mass transfer in UF, Biotechnol. Bioeng. 34 (1989) 171-179.

[45] Tanford C., Physical chemistry of macromolecules, J. Wiley \& Sons Eds, New York, USA, 1961.

[46] Timmer J.M.K., Daufin G., Whey protein concentrates with non-traditional composition, Eur. Dairy Mag. 189 (1997) 47-49.

[47] Troullier A., Reinstädler D., Dupont Y., Naumann D., Forge V., Transient non-native secondary structures during the refolding of $\alpha$-lactalbumin detected by infrared spectroscopy, Nature Struct. Biol. 7 (1992) 78-85.

[48] Wu C., Whey treatment process for achieving high concentration of (A)lactalbumin, Int. Patent Appl. PCT WO 01/ 05243 A1, 2001.

[49] Ye X., Yoshida S., Ng T.B., Isolation of lactoperoxidase, lactoferin, $\alpha$-lactalbumin, $\beta$-lactoglobulin B and $\beta$-lactoglobulin $\mathrm{A}$ from bovine rennet whey using ion exchange chromatography, Int. J. Biochem. Cell Biol. 32 (2000) 1143-1150. 